\title{
Comparative Study of Stability of Soluble and Cell Wall Invertase from Saccharomyces cerevisiae
}

\author{
Aleksandra Margetić ${ }^{1,}$, Zoran Vujčić ${ }^{2}$ \\ ${ }^{1}$ Institute of Chemistry, Technology and Metallurgy, Department of Chemistry, \\ University of Belgrade, Belgrade, Serbia, ${ }^{2}$ Faculty of Chemistry, Department of \\ Biochemistry, University of Belgrade, Belgrade, Serbia. \\ Corresponding author Aleksandra Margetić, Address: Center of Chemistry; Institute of \\ Chemistry, Technology and Metallurgy, University of Belgrade, Studentski trg 12-16, \\ 11000 Belgrade, Serbia. E-mail: aleksandra@chem.bg.ac.rs.
}

\begin{abstract}
Yeast Saccharomyces cerevisiae is the most significant source of enzyme invertase. It is mainly used in the food industry as a soluble or immobilized enzyme. The greatest amount of invertase is located in the periplasmic space in yeast. In this work it was isolated two forms of enzyme from yeast $S$. cerevisiae cell, soluble and cell wall invertase (CWI). Both forms of enzyme showed same temperature optimum $\left(60^{\circ} \mathrm{C}\right)$, similar $\mathrm{pH}$ optimum and kinetic parameters. The significant difference between these biocatalysts was observed in their thermal stability, stability in urea and methanol solution. At $60^{\circ} \mathrm{C}$ $\mathrm{CWI}$ had 1.7 times longer half life than soluble enzyme, while at $70^{\circ} \mathrm{C} \mathrm{CWI}$ showed 8.7 times longer half life than soluble enzyme. After $2 \mathrm{~h}$ incubation in $8 \mathrm{M}$ urea solution soluble invertase and CWI retained $10 \%$ and $60 \%$ of its initial activity, respectively. During $22 \mathrm{~h}$ incubation of both enzymes in 30 and $40 \%$ methanol soluble invertase was completely inactivated, while CWI changed its activity within the experimental error. Therefore, soluble and CWI invertase have not shown any substantial difference, but CWI showed better thermal stability and stability in some of typical protein denaturing agents.
\end{abstract}


$<$ KWD>cell wall invertase, Saccharomyces cerevisiae, enzyme stability, urea, methanol

\section{INTRODUCTION}

Yeast has traditionally been an important source of enzymes. The enzyme invertase, which catalyses the hydrolysis of sucrose into glucose and fructose, is commercially produced from baker's yeast. Soluble yeast invertase (EC 3.2.1.26) exists in two forms (1): external (glycosylated) and internal (nonglycosylated) form. A glycosylated form of invertase is significantly more stable than nonglycosylated form (2). Glycosylation is found to stabilize the protein with respect to thermal denaturation (3). The Saccharomyces cerevisiae cell wall is composed of about $80-85 \%$ carbohydrates, the rest consisting of proteins interspersed throughout the carbohydrate network (4). During the 1970s various kinds of evidence have indicated strongly that invertase is situated close to the cell wall surface in the periplasmic space (5).

Since invertase has been used to a great extent in the food industry in the production of the invert sugar, thermal stability of the enzyme is one of the most important enzyme's characteristics. Invert sugar has found many applications in the food and drink industry $(6,7)$. Immobilization can improve thermal stability of enzymes (8). Immobilized yeast invertase has been the major enzyme used for commercial production of invert sugar (9). Development of better and cheaper biocatalyst is a challenge for many research groups and resulted in a large number of publications. Invertase has been immobilized by adsorption, entrapment, microencapsulation and covalent immobilization (10) to various 
insoluble carriers including ion-exchange resins $(11,12)$, synthetic polymers $(13)$, animal charcoal (14), microporous glass (15), magnetite particles (16) and other inorganic materials (17), DEAE-cellulose (18), corn stover (19), triacetate-cellulose fibers (20), gelatin (21), hen egg-white (22), wool fibers (23) and different hydrogels (24). The main disadvantage of using soluble invertase for immobilization is the loss or inactivation of the enzyme during and after immobilization $(25,26)$ and needs to be removed from some products.

Since, in the yeast cells invertase is firmly bound to the insoluble structure of the cell it can be isolated as the cell wall and used like natural immobilized enzyme. The advantage of using CWI instead of soluble invertase for immobilization in different hydrogels was published previously $(9,27)$. Whole yeast cell can be used for immobilization by entrapment in some conducting polymers instead of soluble invertase, which provides using the cheaper enzyme in industry (28). The main advantages of obtained biocatalysts were high yield of immobilization, absence of enzyme leakage and high thermal stability. The possibility of obtaining immobilized invertase without loss and leakage of enzyme has enormous importance of using these biocatalysts in food and pharmaceutical industry.

The aim of this work was to examine and compare enzyme properties, with the focus on stability, of soluble and cell wall invertase. Since, these are two forms of enzyme, soluble and insoluble cell wall invertase, if they have same enzyme characteristics CWI could be used as a cheaper substituent of soluble enzyme. Both forms of enzyme were isolated from the same yeast strain. Various parameters important for enzyme characterization 
were studied, such as the kinetic parameters $\left(K_{\mathrm{M}}, V_{\max }, E_{\mathrm{a}}\right)$, as well as $\mathrm{pH}$ and temperature optima, $\mathrm{pH}$ and thermal stability. Stability of soluble and CWI invertase in the presence of some well known protein denaturing agents were examined in detail.

\section{EXPERIMENTAL}

\section{Chemicals}

Baker's yeast was obtained from a local market. All other chemicals were analytical grade (or higher) and were purchased from Sigma-Aldrich (St. Louis, MO, USA) and Merck (Darmstadt, Germany).

\section{Enzyme Isolation}

Soluble invertase and CWI was isolated by autolysis of baker's yeast. Soluble invertase was isolated from crude cell extract by isoelectric precipitation, ethanol precipitation and ion-exchange on QAE-Sephadex as previously described (29). Isoform EINV2 was used for comparison. CWI was isolated from slurry obtained after cell autolysis as described in our previously published paper (9). Briefly, the obtained slurry was diluted with an equal volume of $1 \%$ sodium chloride and mixed for $30 \mathrm{~min}$. The yeast cell wall was centrifuged, and the pellet was resuspended in 5 volumes of distilled water. The procedure was repeated until proteins could no longer be detected in the supernatant. The resulting solid material was defatted and dried using cold acetone. The pellet was left to dry overnight at room temperature.

\section{Scanning Electron Microscopy}


The morphological characteristics of the CWI were assessed by scanning electron microscopy using model JSM-6610LV; JEOL, Ltd., USA.

\section{Enzyme Activity Assay}

Enzyme activity assay was performed in a batch reactor at $25^{\circ} \mathrm{C}$. Fifty microliters of the enzyme was mixed with $450 \mu \mathrm{L}$ of sucrose solution $\left(0.3 \mathrm{~mol} \mathrm{~L}^{-1}\right.$ in $50 \mathrm{mmol} \mathrm{L}^{-1}$ acetate buffer, $\mathrm{pH} 4.5$ ). After 5 minutes reaction was stopped by the addition of DNS reagent $(500 \mu \mathrm{L})$ and heated in boiling water bath for $5 \mathrm{~min}$. After cooling to room temperature and dilution with $4 \mathrm{~mL}$ of water, the amount of reducing sugars was determined spectrophotometrically at $540 \mathrm{~nm}$ (30) using a Philips UV/VIS/NIR PU 8630 spectrophotometer (L. G. Philips-Displays Blackburn, U.K.). One international unit (IU) of enzyme activity is defined as the amount of enzyme that hydrolyzes one micromole of sucrose per minute under the assay conditions.

\section{Determination Of Optimum Ph And Ph Stability}

The effect of $\mathrm{pH}$ on the activity of soluble and cell wall invertase was studied at various $\mathrm{pH}$ values at $25^{\circ} \mathrm{C}$. $\mathrm{pH}$ of the reaction mixtures was varied in the range of $2.5-8.0(0.05$ mol L ${ }^{-1}$ glycine-HCl buffer at $\mathrm{pH} 2.5$ was used, $0.05 \mathrm{~mol} \mathrm{~L}^{-1}$ acetate buffer in the range of 3.0-5.6 and $0.05 \mathrm{~mol} \mathrm{~L}^{-1}$ phosphate buffer in the range of 5.7-8.0 was used). The reaction conditions were as described in the previous section

The effect of $\mathrm{pH}$ was studied at $25^{\circ} \mathrm{C}$ at two $\mathrm{pH}$ values, 3.0 and 4.5 . In order to determine $\mathrm{pH}$ stability, both enzymes were dissolved in $50 \mathrm{mmol} \mathrm{L}^{-1}$ acetate buffer of various $\mathrm{pH}$ 
values (3.0 and 4.6) and allowed to incubate for various time intervals from 24 to 168 hours. After incubation period activity of the enzymes was tested as described earlier.

\section{Determination Of Optimum Temperature And Thermal Stability}

The effect of temperature on the activity of enzymes was studied by performing the reaction in the temperature range $20-75{ }^{\circ} \mathrm{C}$ (with $5{ }^{\circ} \mathrm{C}$ increments). The reaction conditions were as described in the previous section and in the paper published previously (9).

Soluble and cell wall invertase were incubated at selected temperatures in $50 \mathrm{mmol} \mathrm{L}^{-1}$ acetate buffer $\mathrm{pH}$ 4.5. Enzymes were allowed to incubate for various times duration (for 420 minutes at $60^{\circ} \mathrm{C}$ and for 15 minutes at $70^{\circ} \mathrm{C}$ ) during which time enzyme activity was monitored as described in the previous section.

\section{Determination Of Kinetic Parameters}

The activation energy of soluble invertase and CWI was calculated using the Arrhenius equation after measuring enzyme activities at different temperatures (31).

Michaelis-Menten kinetic was established by studying the effect of substrate

concentration (1-200 mmol L $\mathrm{m}^{-1}$ for soluble enzyme and 1-400 $\mathrm{mmol} \mathrm{L}^{-1}$ for cell wall invertase) on the reaction rate at $25^{\circ} \mathrm{C} . K_{\mathrm{M}}$ and $V_{\max }$ values were obtained using nonlinear regression (Graph Pad Prism 5.0).

\section{Stability Of Enzymes In Urea And Methanol Solution}


Enzymes were allowed to preincubate in several concentrations of urea (1-8 $\left.\mathrm{mol} \mathrm{L}^{-1}\right)$ and methanol (30-50\%) solution in $50 \mathrm{mmol} \mathrm{L}^{-1}$ acetate buffer $\mathrm{pH} 4.5$ at $25^{\circ} \mathrm{C}$ for $22 \mathrm{~h}$, during which time enzyme activity was monitored (after preparing the sample) as described in the previous section.

\section{Statistical Analysis}

Each data point represents the mean of three independent assays. Statistical significance was determined by standard deviation (SD). The data in Fig. 2-7 are presented as the mean \pm standard error of the mean (SEM).

\section{RESULTS AND DISCUSSION}

Enzymes isolated from different sources, including different strains of the same microorganism not have same characteristics (32-34). Cell wall invertase has significantly lower price than soluble enzyme, because the isolation method and procedures are simpler and faster. Therefore, using of this form of invertase in several industrial fields may have great significance.

Activity of enzyme solutions used in this work was similar. Suspension of cell wall invertase in a concentration of $1 \mathrm{mg} / \mathrm{mL}$ has average activity $10 \pm 2 \mathrm{U} / \mathrm{mL}$, and soluble enzyme was diluted to have similar activity. Scanning electron microscopy was used to observe the surface morphologies and shape of obtained cell wall invertase. Purified cell walls after autolysis, like after disrupting the cells in a mechanical homogenizer (4), has 
produced cracks in the wall through which cell content leaks out leaving empty cell walls, still having the original shape of the cell (Fig. 1).

\section{Determination Of Optimum Ph And Ph Stability}

Enzymes activity dependence of $\mathrm{pH}$ value of reaction mixture was studied using substrate solutions at different $\mathrm{pH}$ at $25^{\circ} \mathrm{C}$. Four isoforms of invertase isolated from the yeast $S$. cerevisiae has reported $\mathrm{pH}$ optimum in the range of $3.5-5.0$ (29). Soluble and CWI invertase isolated in this work showed maximum activity at $\mathrm{pH} 4.6$ and 4.0 , respectively (Fig. 2). Similar pH optimum for soluble invertase was previously reported (35). Slight shift in $\mathrm{pH}$ optimum of soluble invertase and invertase immobilized on insoluble carriers is a common phenomenon described in previous research papers $(9,36,37)$. A change in $\mathrm{pH}$ optimum of immobilized compared with free enzyme usually is caused by changes in $\mathrm{pH}$ value of enzyme microenvironment. CWI showed significantly higher activity at $\mathrm{pH}$ below the optimum than soluble enzyme.

Invertase is one of the most used enzymes in different industries. Production of invert sugar is one of the industrial processes where this enzyme is utilized. The low $\mathrm{pH}$ value of sugar solution is one of the advantages for industrial invert sugar production, as this condition prevents microbial contamination (38). Since, CWI showed at $\mathrm{pH}$ values $2.5-$ 3.5 enzyme activity only $10 \%$ less than at $\mathrm{pH}$ value where it has maximum activity, $\mathrm{pH}$ stability was examined in terms of potential industrial usage of CWI for invert sugar production at lower $\mathrm{pH}$ value. The $\mathrm{pH}$ stability of both forms of the enzyme was tested at two $\mathrm{pH}$ values. Enzymes were incubated at $\mathrm{pH} 3.0$ and 4.5 at $25^{\circ} \mathrm{C}$ during one week. 
After 168 hours incubation of both biocatalysts at $\mathrm{pH} 4.5$ were observed insignificant changes in enzyme activity, under the experimental errors. Therefore, both forms of invertase showed great $\mathrm{pH}$ stability at $\mathrm{pH}$ equal or near their $\mathrm{pH}$ optimum values, while at pH 3.0 soluble and CWI invertase have shown significantly different stability. After 20 hours soluble invertase incubated in the buffer $\mathrm{pH}$ value 3.0 completely lost the activity, while CWI retained more than $86 \%$ of its initial activity after 1 week of incubation.

\section{Determination Of Optimum Temperature And Thermal Stability}

The effect of temperature dependence of enzyme activity was determined within a range from 20 to $75^{\circ} \mathrm{C}$. Both biocatalysts showed the same temperature dependence with maximal activity at $60{ }^{\circ} \mathrm{C}$ (Fig. 3). Activities of enzymes were $50 \%$ and more in the temperature between 40 and $65^{\circ} \mathrm{C}$, while between 65 and $70{ }^{\circ} \mathrm{C}$ enzymes lost more than $50 \%$ of their activity. Same temperature optimum was reported in many of previous public research papers for invertase activity of whole cell and soluble invertase from $S$. cerevisiae $(29,39-41)$.

The stability of enzymes is the most important for their use in some process. Improvement of enzyme stability for industrial process means reduction of production cost and products. The most of enzymatic processes are faster at increasing temperature, while the stability of enzymes decreasing with increasing temperature. At higher temperatures, unfolding of enzyme is responsible for its inactivation. The design of every industrial process should include studies in detail of these factors. Temperature stabilities of enzymes which are the subject of this paper were studied at 60 and $70{ }^{\circ} \mathrm{C}$. Enzymes 
were incubated at both temperature and their activities were measured in determined intervals, during 7 hours at $60{ }^{\circ} \mathrm{C}$ or 15 minutes at $70{ }^{\circ} \mathrm{C}$. The kinetic parameters of the thermal denaturation data of the soluble invertase and CWI were calculated and shown in table 1 . Thermal stability of CWI is significantly higher than soluble invertase. At $60{ }^{\circ} \mathrm{C}$ CWI has 1.7 times longer half life. However, at the $70{ }^{\circ} \mathrm{C}$ difference between those two forms of invertase is highlighted, since CWI showed 8.7 times longer half life than soluble enzyme (Table 1). Similar observations have been reported, previously, for various immobilized systems (24).

\section{Determination Of Kinetic Parameters}

Initial activities were determined for different sucrose concentration at room temperature and $\mathrm{pH}$ 4.5. $V_{\max }$ and $K_{\mathrm{M}}$ values were calculated using nonlinear regression. The obtained values of soluble and CWI invertase are given in Table 2. The Michaelis-Menten constant, $K_{\mathrm{M}}$, is an important parameter for the characterization of an enzyme. It indicates the affinity of the enzyme for the substrate. Also, the maximum reaction rate, $V_{\max }$, is another parameter in enzyme kinetics studies. Comparison of $K_{\mathrm{M}}$ value of different forms of the same enzyme gives important information about enzymes catalytic activity. $K_{\mathrm{M}}$ values of the immobilized enzymes are often higher than those of the free ones (42) because of the possible conformational changes in the enzyme molecule by the immobilization process and/or diffusion limitation on the transfer of the substrate molecules into the particle. Determined values of kinetic constants for soluble and CWI invertase had similar values (Table 2). These results indicate that soluble and CWI invertase have very similar affinity for the substrate, without diffusion limitation. 
Enzyme activities were determined at different temperature at $\mathrm{pH} 4.5 \mathrm{using} 0.3 \mathrm{~mol} \mathrm{~L}^{-1}$ sucrose solution to find activation energies for soluble and CWI invertase. Arrhenius plots are given in Fig. 4. Activation energies of two isolated biocatalysts were found to be the similar values (Table 2). The obtained results are very close to the data published previously, for soluble invertase and whole yeast cells $(43,44)$. Miyamato et al. indicated that changes in activation energies are caused by diffusion and enzyme modification (45). Whereas, value of the activation energy for CWI was similar to the value for the soluble enzyme can be concluded that diffusion limits are not present.

\section{Stability Of Enzymes In Urea And Methanol Solution}

Comparison the stability of soluble invertase and CWI was performed in the presence of some well known protein denaturing agents, urea and methanol. Many researchers reported that during the denaturation of some enzymes by urea, inactivation occurs before any noticeable conformation. The same results were reported by Li et al. for external yeast invertase (46). The enzyme activity of soluble invertase and CWI was measured during 120 minutes and after $22 \mathrm{~h}$ incubation in urea solutions concentration $1-8 \mathrm{~mol} \mathrm{~L}$ 1.

During 120 minutes of incubation of two forms of invertase in solutions of $2 \mathrm{~mol} \mathrm{~L}^{-1}$ or less concentration of urea was not observed any difference in stability (data not shown), but in higher urea concentrations were observed considerably higher stability of CWI compared to the soluble enzyme (Fig. 5). CWI did not change its activity nor had a 
significant decrease of activity after 2 hours incubation in $3-5 \mathrm{~mol} \mathrm{~L}^{-1}$ urea solution, while soluble invertase showed lower stability. Stability of both enzymes in urea solutions $6 \mathrm{~mol} \mathrm{~L}^{-1}$ or more is lower, but the stability of CWI in all of the urea solutions is significantly higher. It is well established that the activity of enzymes strongly depends on their maintenance of conformational integrity. Structural study of invertase molecules showed slight and similar changes in the protein structure in the presence of urea solution $3 \mathrm{~mol} \mathrm{~L}^{-1}$ or less, but it was also reported that structural changes increase with increasing concentration of urea (46).

Methyl alcohol is well known as protein denaturing agents; however one of the steps in the purification of invertase is precipitation of this enzyme in $50 \%$ alcohol solution. Nevertheless, there is a reaction which includes usage of invertase in alcohol solutions (47). Invertase is capable of transferring fructose to water (hydrolysis) and to alcohols (alcoholysis). The major drawback is low enzyme activity and stability in the presence of alcohols. Also, the stability of invertase decreasing with increasing chain length and decrease polarity of aliphatic alcohol (48). Therefore, the stability of the CWI in alcohol solution was studied. Both tested forms of invertase did not change its activity during $2 \mathrm{~h}$ of incubation in $30 \%$ methanol solution (data not shown), but in higher concentration of alcohol activity of soluble enzyme decrease with increasing time of incubation (Fig. 6) during the first $2 \mathrm{~h}$ of incubation. The decreasing enzyme activity of the CWI was observed just in the highest concentration of methanol (50\%). Higher half life of whole cell derivate with invertase activity then soluble in methanol solution was reported previously (47), but stability studies with free and covalent immobilized soluble invertase 
showed that immobilization does not favor enzyme stability in the presence of methanol (48).

In Fig. 7 is reported residual activity of soluble invertase and CWI after $22 \mathrm{~h}$ incubation in two of typical proteins denaturing agents. The greatest difference in stability of these two forms of biocatalyst is observed in all used concentrations of methanol. Therefore, these results suggest that invertase in CWI has less molecular flexibility than in soluble form, what causes better stability.

\section{CONCLUSION}

Comparison of catalytic properties of soluble and CWI invertase have not shown any substantial difference between these two forms of the same enzyme. On the other side CWI showed better thermal stability and stability in some of typical protein denaturing agents. Lower price, simpler and faster method of isolation is some of the great advantages of the CWI in regard to soluble invertase. Stability at low $\mathrm{pH}$ values could be a great advantage for the substitution of soluble enzyme in invert sugar production as well as stability in the alcohol solution for the synthesis of alkylglycosides.

\section{ACKNOWLEDGEMENTS}

This work was supported by the Serbian Ministry of Education, Science and Technological Development (project grant number 172048). We are grateful to Dr. Vladica Cvetković, Dr. Aleksandar Pančevski and project RESTCA-TERCE-NIPMSS for scanning electron microscopy analysis. 


\section{REFERENCES}

1. Gascon S.; Lampen J.O. Purification of the internal invertase of yeast. Journal of Biological Chemistry. 1968, 243 (7), 1567-1572.

2. Gascon S.; Neumann N.P.; Lampen J.O. Comparative study of the properties of the purified internal and external invertases from yeast. Journal of Biological Chemistry. 1968, 243 (7), 1573-1577.

3. Chu F.K.; Trimble R.B.; Maley F. The effect of carbohydrate depletion on the properties of yeast external invertase. Journal of Biological Chemistry. 1978, 253 (24), 8691-8693.

4. Vukovic R.; Mrsa V. Structure of the Saccharomyces cerevisiae cell wall. Croatica Chemica Acta. 1995, 68 (3), 597-605.

5. Arnold W.N. Location of acid phosphatase and $\beta$-fructofuranosidase within yeast cell envelopes. J Bacteriol. 1972, 112 (3), 1346-1352.

6. Buchholz K.; Kasche V.; Bornscheuer U.T. Biocatalysts and Enzyme Technology. Weinheim: WILEY-VCH Verlag GmbH \& Co. KGaA, 2005.

7. Lindamood J.B., Grooms D.J.; Hansen P.M.T. Effect of hydrolysis of lactose and sucrose on firmness of ice cream. Food Hydrocolloids. 1989, 3 (5), 379-388.

8. Martinek K.; Mozhaev V.V. Practical Importance of Enzyme Stability .2. Increase of Enzyme Stability by Immobilization and Treatment with Low-Molecular-Weight Reagents. Pure Appl Chem. 1991, 63 (10), 1533-1537.

9. Milovanovic A.; Bozic N.; Vujcic Z. Cell wall invertase immobilization within calcium alginate beads. Food Chem. 2007, 104 (1), 81-86. 
10. Amaya-Delgado L.; Hidalgo-Lara M.E.; Montes-Horcasitas M.C. Hydrolysis of sucrose by invertase immobilized on nylon-6 microbeads. Food Chem. 2006, 99 (2), 299304.

11. Kobayashi T.; Moo-Young M. The kinetic and mass transfer behavior of immobilized invertase on ion-exchange resin on beads. Biotechnology and Bioengineering. 1973, 15 (1), 47-67.

12. Tomotani E.J.; Vitolo M. Screening of Dowex anion-exchange resins for invertase immobilization. Appl Biochem Biotechnol. 2004, 113-116 145-159.

13. Prodanovic R.; Jovanovic S.; Vujcic Z. Immobilization of invertase on a new type of macroporous glycidyl methacrylate. Biotechnol Lett. 2001, 23 (14), 1171-1174.

14. Nelson J.M.; Griffin E.G. Adsorption of invertase. Journal of the American Chemical Society. 1916, 38 (5), 1109-1115.

15. Mason R.D.; Weetall H.H. Invertase covalently coupled to porous glass: preparation and characterization. Biotechnology and Bioengineering. 1972, 14 (4), 637-645.

16. Van Leemputten E.; Horisberger M. Immobilization of enzymes on magnetic particles. Biotechnology and Bioengineering. 1974, 16 385-396.

17. Danisman T.; Tan S.; Kacar Y.; Ergene A. Covalent immobilization of invertase on microporous pHEMA-GMA membrane. Food Chem. 2004, 85 (3), 461-466.

18. Suzuki H.; Ozawa Y.; Maeda H. Studies on the water-insoluble enzyme hydrolysis of sucrose by insoluble yeast invertase. Agricultural and Biological Chemistry. 1966, 30 (8), 807-812.

19. Monsan P.; Combes D.; Alemzadeh I. Invertase covalent grafting onto corn stover. Biotechnology and Bioengineering. 1984, 26 (7), 658-664. 
20. Marconi W.; Gulinelli S.; Morisi F. Properties and use of invertase entrapped in fibers. Biotechnology and Bioengineering. 1974, 16 501-511.

21. Kennedy J.F.; Kalogerakis B.; Cabral J.M.S. Surface immobilization and entrapping of enzymes on glutaraldehyde crosslinked gelatin particles. Enzyme and Microbial Technology. 1984, 6 (3), 127-131.

22. D'Souza S.F.; Nadkarni G.B. Hen Egg White: A Novel Support for the Immobilization of Enzymes. Biotechnology and Bioengineering. 1981, 23 (2), 431-436. 23. Krastanov A. Continuous sucrose hydrolysis by yeast cells immobilized to wool. Appl Microbiol Biot. 1997, 47 (5), 476-481.

24. Kotwal S.M.; Shankar V. Immobilized invertase. Biotechnol Adv. 2009, 27 (4), 311322.

25. Tanriseven A.; Dogan S. Immobilization of invertase within calcium alginate gel capsules. Process Biochem. 2001, 36 (11), 1081-1083.

26. Woodward J.; Wiseman A. The involvement of salt links in the stabilization of baker's yeast invertase. Evidence from immobilization and chemical modification studies. Biochim Biophys Acta. 1978, 527 (1), 8-16.

27. Vujcic Z.; Miloradovic Z.; Milovanovic A.; Bozic N. Cell wall invertase immobilisation within gelatin gel. Food Chem. 2011, 126 (1), 236-240.

28. Yildiz H.B.; Kamaci M.; Azak H.; Secgin O.; Suer O. A comparative study: Immobilization of yeast cells and invertase in poly(ethyleneoxide) electrodes. Journal of Molecular Catalysis B-Enzymatic. 2013, 91 52-58. 
29. Andjelkovic U.; Picuric S.; Vujcic Z. Purification and characterisation of Saccharomyces cerevisiae external invertase isoforms. Food Chem. 2010, 120 (3), 799804.

30. Bernfeld P. Amylases alpha and beta. Methods in Enzymology. 1955, 1 149-158. 31. Hartmeier W. Immobilized biocatalysts. Berlin: Springer, 1988.

32. Dworschack R.G.; Wickerham L.J. Production of Extracellular and Total Invertase by Candida utilis, Saccharomyces cerevisiae, and Other Yeasts. Applied and Environmental Microbiology. 1961, 9 (4), 291-294.

33. Carlson M.; Osmond B.C.; Botstein D. Mutants of yeast defective in sucrose utilization. Genetics. 1981, 98 (1), 25-40.

34. Rehill B.J.; Schultz J.C. Enhanced invertase activities in the galls of Hormaphis hamamelidis. J Chem Ecol. 2003, 29 (12), 2703-2720.

35. da Silva A.R.; Tomotani E.J.; Vitolo M. Invertase, glucose oxidase and catalase for converting sucrose to fructose and gluconic acid through batch and membrane-continuous reactors. Braz J Pharm Sci. 2011, 47 (2), 399-407.

36. Emregul E.; Sungur S.; Akbulut U. Polyacrylamide-gelatine carrier system used for invertase immobilization. Food Chem. 2006, 97 (4), 591-597.

37. Akgol S.; Kacar Y.; Denizli A.; Arica M.Y. Hydrolysis of sucrose by invertase immobilized onto novel magnetic polyvinylalcohol microspheres. Food Chem. 2001, 74 (3), 281-288.

38. Kaur N.; Sharma A.D. Production, optimization and characterization of extracellular invertase by an actinomycete strain. J Sci Ind Res India. 2005, 64 (7), 515-519. 
39. Godbole S.S.; Kubal B.S.; D'Souza S.F. Hydrolysis of concentrated sucrose syrups by invertase immobilized on anion exchanger waste cotton thread. Enzyme Microb Technol. 1990, $12(3), 214-217$.

40. D'Souza S.F.; Nadkarni G.B. Continuous inversion of sucrose by gel-entrapped yeast cells. Enzyme and Microbial Technology. 1980, 2 (3), 217-222.

41. D'Souza S.F.; Melo J.S. Immobilization of bakers yeast on jute fabric through adhesion using polyethylenimine: application in an annular column reactor for the inversion of sucrose. Process Biochem. 2001, 36 (7), 677-681.

42. Arica M.Y.; Bayramoglu G. Invertase reversibly immobilized onto polyethyleniminegrafted poly(GMA-MMA) beads for sucrose hydrolysis. Journal of Molecular Catalysis B-Enzymatic. 2006, 38 (3-6), 131-138.

43. Ikram-Ul-Haq; Ali S. Kinetics of invertase production by Saccharomyces cerevisiae in batch culture. Pakistan J Bot. 2007, 39 (3), 907-912.

44. Parascandola P.; Scardi V. Gelatin-Entrapped Whole-Cell Invertase. Biotechnol Lett. 1981, 3 (7), 369-374.

45. Miyamoto K.; Fujii T.; Tamaoki N.; Okazaki M.; Miura Y. Intraparticle diffusion in the reaction catalyzed by immobilized glucoamylase. Journal of Fermentation Technology. 1973, 51 566-574.

46. Li S.; Yang H.P.; Zhou H.M. Inactivation and conformational changes of yeast invertase during unfolding in urea and guanidinium chloride solutions. J Pept Res. 1998, $51(1), 45-48$. 
47. Rodrigues M.; Gomez A.; Gonzalez F.; Barzana E.; Lopez-Munguia A. Stability of invertase in alcoholysis reaction with methanol. Journal of Molecular Catalysis BEnzymatic. 1997, 2 299-306.

48. Ulbrich-Hofmann R.; Selisko B. Soluble and Immobilized Enzymes in WaterMiscible Organic-Solvents - Glucoamylase and Invertase. Enzyme and Microbial Technology. 1993, 15 (1), 33-41. 
Table 1. Half life of CWI and soluble invertase.

\begin{tabular}{|l|l|l|}
\hline Enzyme & $\mathrm{t}_{1 / 2}$ at $60{ }^{\circ} \mathrm{C}(\mathrm{min})$ & $\mathrm{t}_{1 / 2}$ at $70{ }^{\circ} \mathrm{C}(\mathrm{min})$ \\
\hline Soluble invertase & 96 & 0.3 \\
\hline CWI & 163 & 2.6 \\
\hline
\end{tabular}


Table 2. Kinetic parameters for CWI and soluble invertase

\begin{tabular}{|l|l|l|l|}
\hline Enzyme & $E_{\mathrm{a}}(\mathrm{kJ} / \mathrm{mol})$ & $K_{\mathrm{M}}(\mathrm{mM})$ & $V_{\max }(\mathrm{mM} / \mathrm{min})$ \\
\hline Soluble invertase & 35.7 & 29.6 & 19.8 \\
\hline CWI & 36.4 & 30.9 & 11.6 \\
\hline
\end{tabular}


Figure 1.

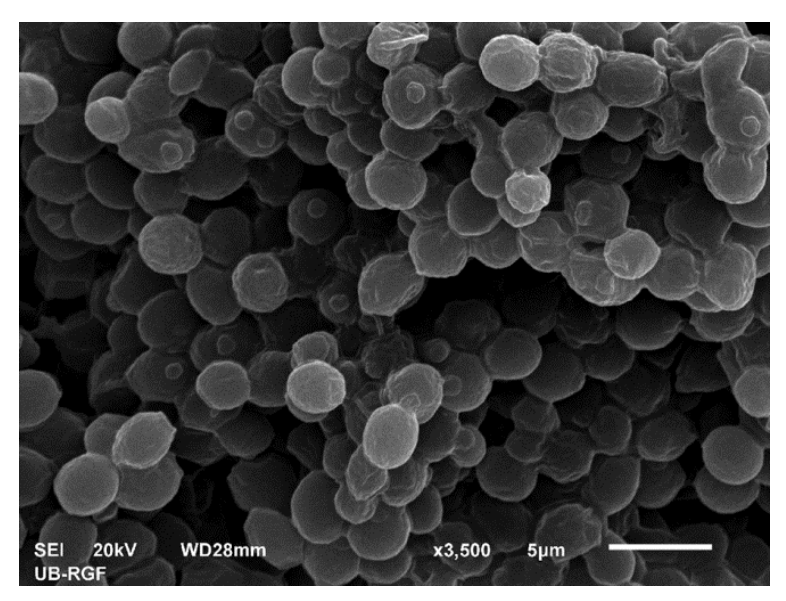


Figure 2.

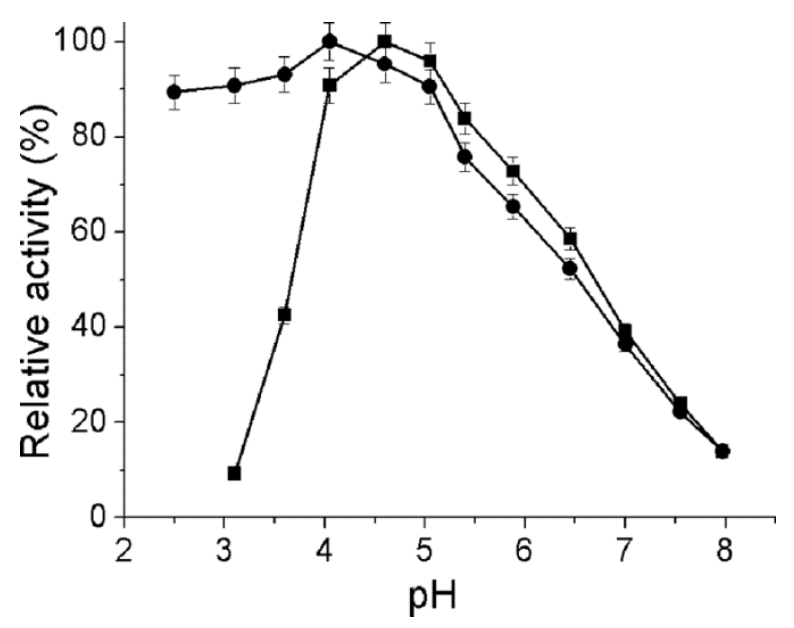


Figure 3.

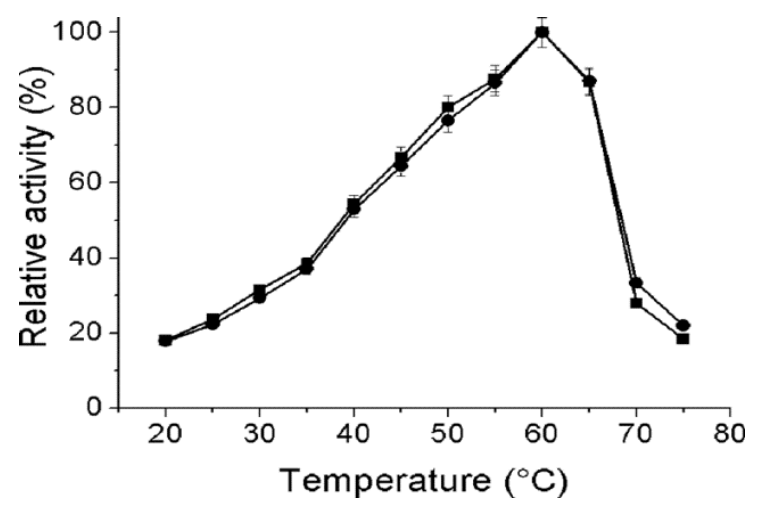


Figure 4.

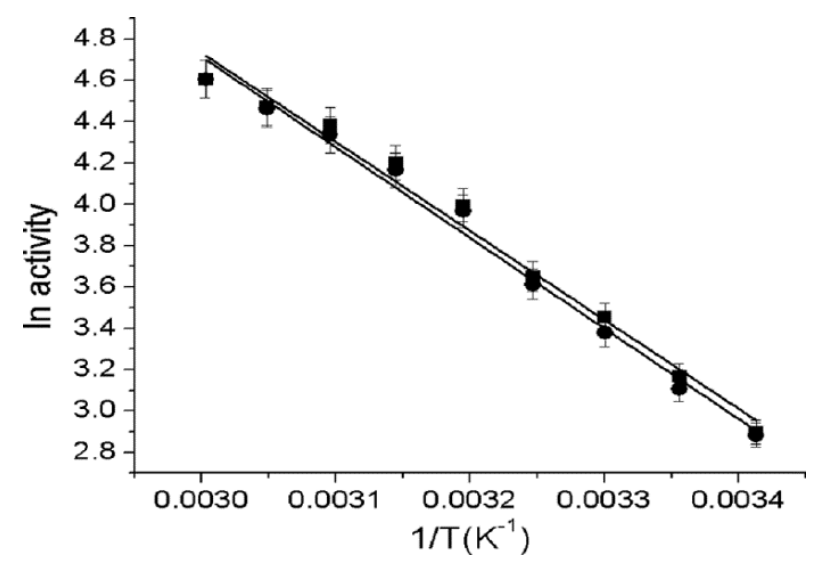


Figure 5.
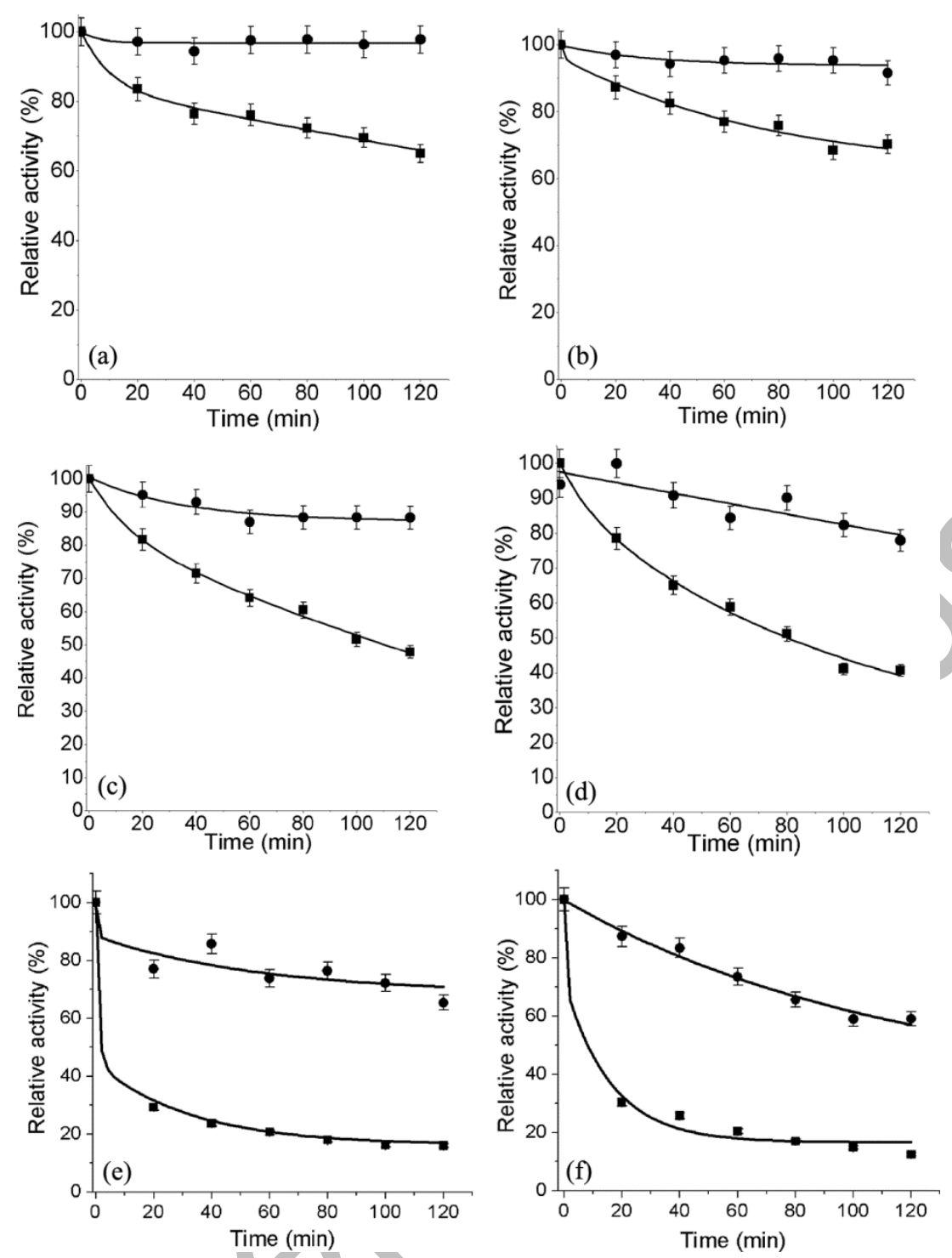
Figure 6.

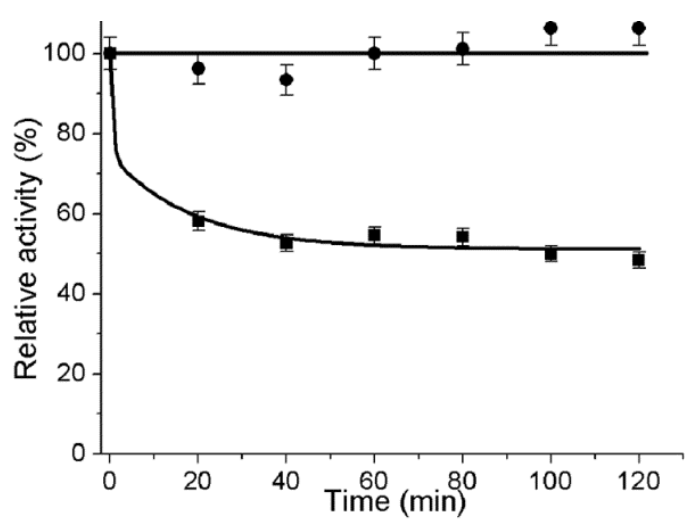

(a)

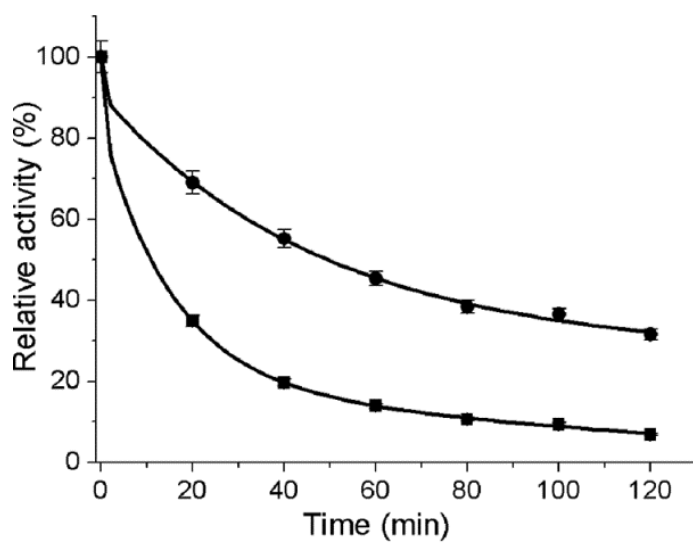

(b)

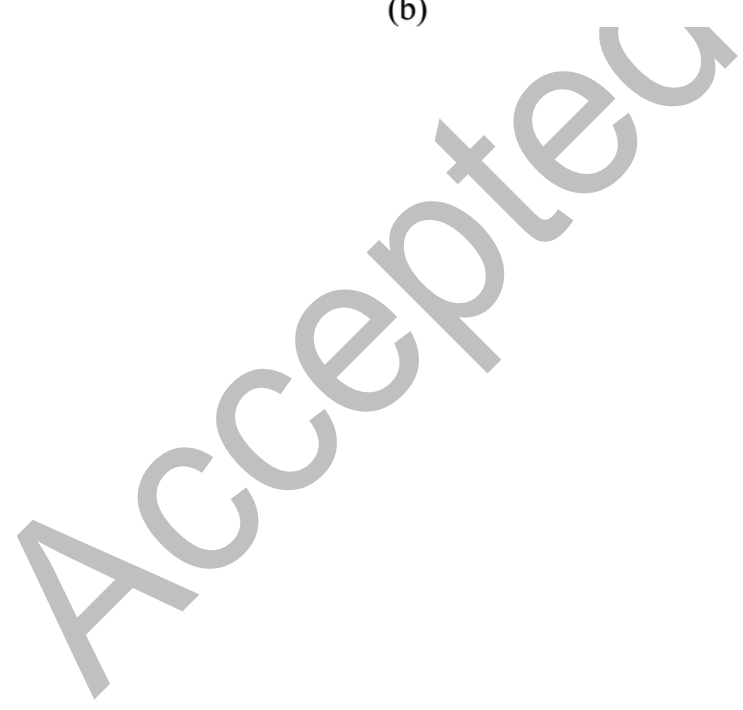


Figure 7.

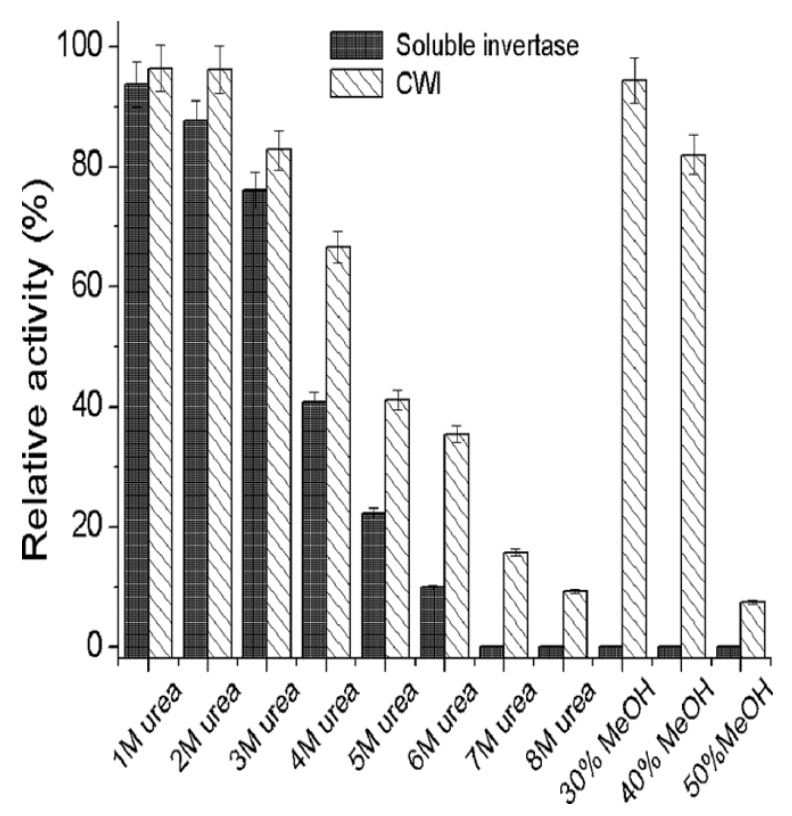

